\title{
Guided Lecture of Synthetic Resins \\ for Paint Industry (XV) \\ 塗装と接着のレオロジー
}

塗料用樹脂入門講座 $(\mathbf{1 5})^{*} \quad$ : $5672.621 .633^{\prime \prime 12}$ $: 532,135$

Rheologies of Painting and Adhesiveness

垣 内 弘林

Hiroshi KAKIUCHI

12.1 レオロジーとは

高分子物質が他の固体表面にへばりつくといら現象は なかなか複雑な機構をもっている。この現象は塗装や接 着といらょうな実際的な作業においても重要な一つのプ ロセスでもある。このよらなプロセスは液体の形で固体 表面に塗布することによって初めて可能となるが，塗料 や接着剤には高分子物質が用いられているから実際に用 いる液体は, 高分子溶液か融液であろら。これらの特徴 は高分子量の物質の溶液とか融液であるから非常に粘い ことであり，またその他にも低分子物質の溶液などに比 ベていろいろな特徴をもっている。高分子溶液について は高分子溶液論として高分子の学問体系の一つになって いて，主に熱力学や統計力学の問題として取扱われてい る。本稿では塗装といら力学的な仕事として高分子溶液 などを考えていくためにレオロジー的な面からの解説を していこう。

レオロジー (Rheology) とは簡単にいえば物質の変形 と流動に関する科学であり，もっとわかりやすくいえば ある一つの物体が固体の性質である弾性と液体の性質で ある粘性とを兼社備えている。これらはその時に応じて どららかの性質が強く表らわれてくるが，その表らわれ る条件や，そのときの両者の関係を研究するのがレオ口 ジーである。固体の水が集った氷河は流動している。静 かに傾けてもちっとも出てこないトマトケチャップのび ん詰めを, 激しく振り廻してから傾けると，ケチャップ は簡単に流出してくるといらような事柄を体系づけてい

昭 45.1 .26 受理

* (14) 本誌 43 [2] 90 96（1970）

** 横浜国立大学工学部

横浜市南区大岡町
く学間である。

レオロジーを勉強していくには基礎として物体の変形 というものを勉強していく必要がある。固体の变形と流 体の変形は樣子が異なっていて, 前者を弾性変形, 後者 を流動変形と呼んでいる。

\section{2 弾性変形と流動変形}

まず始めに固体の引張り変形を考えてみよう。固体た とえばポリエチレンの細い棒に力を加えて引張っていく と図-1 のような曲線が得られる。

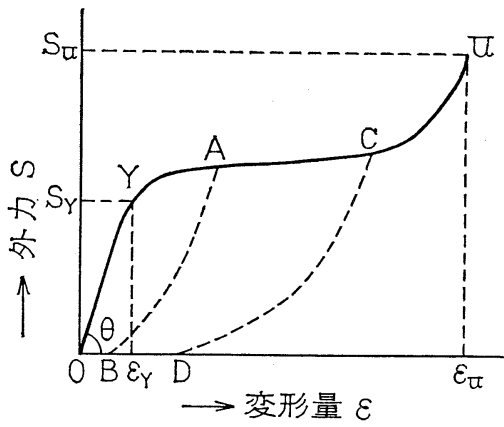

図-1 外力-変形曲線

引張るために加えた外からの力 $S$ は, 太い棒や細い棒 といら差をなくするために単位断面積 $\left(1 \mathrm{~cm}^{2}\right)$ あたりの 值として括くと, $S$ の単位は $\mathrm{kg} / \mathrm{cm}^{2}$ となる。横軸の変 形量 $\varepsilon$ は棒の初めの長さ $l_{0}$ と, 伸びためとの長さ $l$ との 差を元の長さで割った $l-l_{0} / l_{0}=\varepsilon$ とする。図-1 で OY 間は直線的に変化しているから $S$ と $と$ と間につぎのよ らな比例関係が成立する。

$$
\frac{S}{\varepsilon}=E
$$

式 (1)をフックの法則 (Hook's Low) といい, 完全 
な弾性変形の成立する部分である。 $E=\tan \theta$ でめり, 物質によって決まった一定の值をるっていてこれを弾性 率 (modulus) と呼んでいる。外力の加光方, たと光ば 引張り力のときは引張り弾性率(この場注特にヤング率 (Young's modulus) と呼ぶ) となり, 圧縮力なれば压 縮弾性率と呼ぶ。弾性率の単位は $\mathrm{kg} / \mathrm{cm}^{2}$ である。アメ リカでは外力 $S$ を断面積 1 平方インチに対し何ポンドと いら值で示すことがある。このときSの単位は pound per square inch(psi) [1b/in $\left.{ }^{2}\right]$ であり, 弾性率も psi 化 なる。

主なプラスチックのヤング率は表-1（次月号）に示し ておいた。

図-1のY点をすぎると少しの外力の増加で変形は大 きくなる。Y点を通りすぎると固体の内部で流動が始ま り，内部構造が外力のためにずるずる滑ってくる。だか $5 \mathrm{~A}$ 点や $\mathrm{C}$ 点で外力を取去っても, 变形は幾分回復する が $\mathrm{OB}$ とか $\mathrm{OA}$ という永久变形が残ってくる。内部構造 が変化しているからである。 $\mathrm{Y} \rightarrow \mathrm{A} \rightarrow \mathrm{C} \rightarrow \mathrm{U}$ という変化 は, わずかの外力の増加に対して变形の大きな状態,す なわら物体内に内部流動が拈こり易くなり，次に新しい 配列ができて，たと兊ば線状ポリマーでは内部で分子の 再配列が和こり結晶化して, 外力の增加に対してあまり 变形しない状態を通って, 場後にU点で切断される。こ のこときの外力 $S_{U}$ が切断強度（一般には破壊強度）で 离り, $\varepsilon_{U}$ が極限伸度 (一般には極限变形度) である。

外から物体に加える力に対して, 反作用として物体の 内部に外力に抵抗してつり合った力を生じる。これを応 力そ呼んでいるが，両者の大きさは等しく方向は反対で ある。物体中の構造単位の流動などを取报らときには応 力に注目した湾らがよいが，いまのように系全体を議論 するときは外力と応力とを区別しなくてもよい。

弾性変形というものは物体に外力を加兄て変形させた とき，OY 間のように外力を取去ると元に戻るというよ うな可逆的な変形のことであり，この変形量はゴムのよ うな特殊な例をのぞいてあまり大きくはなく，外力と比 例関係索る。金属では原子と原子との間の距離が伸び たりすることであり，ポリマーではとの分子を構成して いる原子の結合角の変化や化学結合の伸びなどによる変 形に起因している。力を加光ると変形し, 力を取去ると 元に戻る性質を弾性 (elasticity) と呼び, 上述の変形の しかたを弾性变形といらわ沙である。

液体の変形は流動変形である。ごくわずかの力で変形 しつづける。力を加えている間ずっと变形しつづけるか ら時間が関倸してくる。固体の場合は力を加えた瞬間に 一定量の変形を生じたのであるが，さらに液体では力を

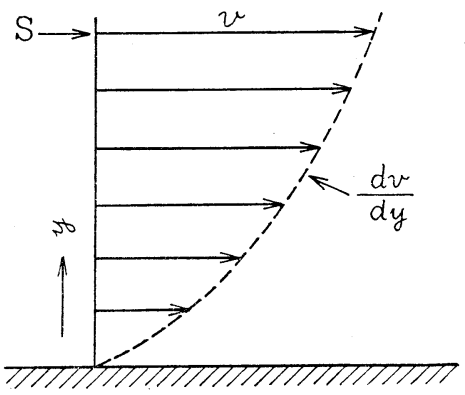

図-2 ニコートン流動に拈ける速度こう配

取去っても元の形に戻らないといら特徴をもっている。 この変形はさきの図-1 でY点を通りすぎためとの $\mathrm{Y} \rightarrow$ $\mathrm{A} \rightarrow \mathrm{C}$ とらカーブに似ている。このことは固体でも山 る条件では流動変形が抢こり得るといらことを暗示して いる。

流動は次の式で与兄られる（ニュートンの式）。

外力 $=$ 粘性 $\times$ 变形速度

粘性とはその流体の粘度のことであり, 流動に対して 抵抗するところの流体の内部摩擦係数である。式 (2)は つぎのように表わされる。

$$
S=\eta \frac{d v}{d y}=\eta \frac{d \varepsilon}{d t}=\eta D
$$

$(d v / d y)$ は図-2 に示したように一つの固定底から $y$ と いう距離の上層面が， $S$ といら外力によって底に平行に 流れるとさの線速度をvとすれば， v といら速度で流れ ている面にくっついている他の面も, それに引張られて $v$ よりちよっと小さい速度で流れる。その差を $d v$ とし, 二枍の面の距離を $d y$ とすれば（ $d$ といら字はとの差が 小さく連続しているといらことを示した記号と考光てい ただきたい)，(dv/dy) 㯈度こう配となる。

$$
\frac{d v}{d y}=D
$$

D洋位の距離あたりいくら速度が異なるかを示して いる。式(3)よりSが大きければ $D$ む大きくなる。クは 比例定数で一つの流体によって決まった值をもってい る。 $\eta$ が大きいと $S$ も大きくなるから，流動に対する固 有抵抗みたいなもので，これを粘性係数と呼ぶわけであ る。

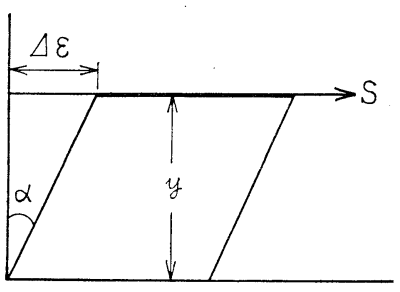

図-3 平行板のずれ变形 
一方式 $(3)$ の変形速度 $d \varepsilon / d t$ は図-3 のようなモデル から理解できる。

$\Delta \varepsilon$ とい变形は $\Delta t$ 時間で $S$ にっておこる。 $\Delta \varepsilon / \Delta t$ は単位時間におこる変形量であり, これは $y$ という距離 によっても異なるから，

$$
\frac{d \varepsilon}{d t}=\frac{1}{d y}\left(\frac{\Delta \varepsilon}{d t}\right)=\frac{d v}{d y}
$$

となる。

流動変形を取扱らには，流れるものを平面の重なった ものと考觉ると便利であった。それぞれの平面が互いに 滑りあって流れる。力を加えた平面が最も速く流れ, 次 第に抢そくなり，器壁では静止している平面と考える。 その滑りに抵抗するものが内部摩擦であり, 粘性係数 ク であり，また平面の滑り難さの割合は速度こう配 $D$ は, 変形速度 $d \varepsilon / d t$ で示される。最後に式 $(3)$ で $S$ の単位は $\mathrm{g} / \mathrm{cm}^{2}$ であり, $v$ は $\mathrm{cm} / \mathrm{sec}, y$ は $\mathrm{cm}$ であから $D$ は $/ \mathrm{sec}$ であり, クは $\mathrm{g} \cdot \mathrm{sec} / \mathrm{cm}^{2}$ であるが, 習慣として $1 \mathrm{~g}$ は約 980 ダイン (dyne) といら流体力学的な単位があり, 換 算してクは dyne· $\mathrm{sec} / \mathrm{cm}^{2}$ といら単位をよく使う。その わ惊粘度の単位にポイズ (poise) というものがあり,

\section{1 poise $=1 \mathrm{dyne} \cdot \mathrm{sec} / \mathrm{cm}^{2}$}

である。1/100 poiseを centipoise といいcp で表わ す。水は $20^{\circ} \mathrm{C}$ で $1.002 \mathrm{cp}$ であり，ヒマシ油は $9.62 \mathrm{p}$. である。

\section{3 塑性流動}

粘性係数を測定するには, 半径 $r$, 長さ $L$ の毛細管に 液体を流す。力 $S$ の代りに圧力pを加え，そのとき毎秒 Qcc が流れ出たとすれば次式が成立する。

$$
\eta=\frac{\pi p r^{4}}{8 Q L}
$$

この式はハーダンポアゼイユの法則といわれている。

水, アルコール，ベンゼンのような一的に液体では圧 力pの大小にかかわらず一定の クの值が得られる。この ように式 $(6)$ に従うような液体をニュートン液体 $(\mathrm{New}$ tonian liquid), またこれらに従う流動をニュートン流 動という正常な粘性流動と呼ぶものである。

ところが粒子の大きくなったコロイド粒子を液体中に 分散してさきの毛細管中に流すと， クとしてpの小さい ときは大きな值が，pが大のときは小さい值が得られ た。測定条件によって異なった值になる。このような流 動を非ニュートン流動といっている。このような現象は 分散しているコロイド粒子は普通の液体の分子よりはる かに大きいので，大きい流速の流体中では容易に配列し て流れの進行方向に向く。これを配向 (orientation) と いらが，配向が执これば流れに対する抵抗が減少し小さ
いクを示す。流速が小さいと粒子はでたらめな方向を向 き，その状態に対応する前よりも大きい一定のクを与光 る。このような例は球状高分子のタバコの葉につくビー ルス，タバコモザイクビールスの分散液などに見出され ている。

もら一つ非ニュートン流動の例がある。粘土やカーボ ンブラックの分散液は静置しておくと, 粒子が互いに連 らなり三次元的な構造をつくり上げている。このような 分散液を毛細管に流すと，小さい流速ではその構造が残 っているために大きな見掛のクの值を与える。压力 $p$ を大にして流速を速くすると，この構造が完全に破壞し て，各粒子はバラバラになり小さなク值を与える。この よらな現象を構造粘性 (structural viscosity) といって いる。

構造粘性の極端な例は, 粘土を水でこねて陶器の原形 をつくる場合である。強い力を加えると液体の上らに容 易に流動するから，いろんな形に成形できる。力を取去 ると固体のようにその形を保っているわけで岕る。デン プンのりもとの例であろら。強い力に対しては粘性流体 であり, 弱い力に対しては無限大の粘性をもったもの, すなおち固体の性質が現われてくる。このような性質を 塑性 (plasticity) あるいは塑性流れ (plastic flow) と呼 んでいる。

塑性をもった物質を可塑物 (plastics) という。しかし このプラスチックス（最近ではプラスチックでもよい） という言葉は，近頃は合成樹脂 (synthetic resin) の代 りに用いられるようになっている。それはいわゆる合成 樹脂があたかも粘土のようにあらゆる形に成形できる可 塑物であるからである。

たとえばポリ塩化ビニルはそのままでは堅い弾性体に 近い。硬質塩ビと呼ばれプラスチックタイルや排水管な どに用いられている。ポリ塩化ビニルに可塑剤としてジ オクチルフタレート (DOP)やトリクレジルホスフェート (TCP) を添加して練ると, 図-4 の(A)弾性体から, 可 塑剂分子が高分子鎖の間に入り込んで鎖同志のからみ合

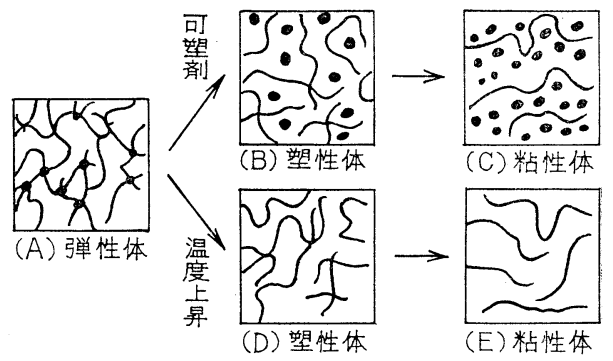

図-4 塑性発現のモデル 


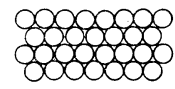

[A]

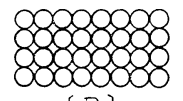

[B]
図-5 粒子の充テン形式

いを弱めて（B）のような形になる。このような形が塑览 体であろう。強い力によって塑性流動を示すので, 成形が 可能となる。可塑剤の量が增加すると高分子鎖が可塑剂 中に溶解し (C)のような粘性体になり粘性流動を示す。

可塑剤の入っていない硬質塩ビを成形するにはどうし たらよいか，答は簡単である(A)のような形のものを加 熱すると，温度上昇によって高分子鎖のからみ合いが弱 まって，(D)のような塑性体の構造をとる。この状態で 自由に成形できる。もっと温度を上げると（E)のように 高分子鎖がばらばらになり液体の形になって流れてしま ら。ポリスチレンやポリエチレンなどはこのような方法 で成形している。だから熱を加兄て可塑性にして成形で きる高分子を熱可塑性高分子 (thermoplastics) と呼え でいる。

石炭酸樹脂や尿素樹脂法熱硬化樹脂(thermosettings) といわれている。この生成の機構は既に述べたが，いう までもなく塑性流動を利用して成形をしてはいない。

\section{4 異常な流動}

波打際の砂をふむと，足のまわりの砂が急に乾いたよ うにみえる。そして足を離した後時間が経つと再びヌレ てくる。この現象について次のように説明されている。

砂粒は重力によって図-5 の (A) の上うに最も密に充 テンしている。これに外力(足でらむこと)が加わると粒 体が流動して充テン様式が変化して図-5 の（B）のよう そなったとすると，図から明らかなように，粒と粒との 間のすきまが大きくなり，そのすきまに水が入り込む。 そのため砂層表面にあった水分が内部沉吸い込まれ，乾 いてみ兄るようになる。

つぎに外力を取り去ると, 再び振動や重力によって元 の $(\mathrm{A})$ のような最密充テンにかえり，寸きまに入った水 分は表面にしみ出てヌレてみえるようになる。

この場合は外力によって，全体の見掛けの体積は膨張 増大したことになるから，この現象をダイラタンシー (dilatancy) といっている。dila といらのは“らくらむ” という意味である。

ダイラタンシーの例は他にも岕る。ジャガイモデンプ ンを少量の水でこ叔たものは，これをかきまぜると固体 のような状態（ゲル状態という）にあるが，それをやめ ると液体状（ゾル状態といら）になる。だからがイラタ ンシーとは外力によってゲル状になり，外力のないとき
はゾル状という現象である。

・゙゙イラタンシーは工業的にも重要な現象であろう。大 量の沈股物を口過しようとしたとき，このダイラタンシ 一が起ると, 静置していると多量の液体を含んでいるこ とがわかるのに，いざ吸引口過しょうと，吸引力を加兄 ると固化してしまう。顔料粒子の入った塗料をパイプ輸 送しようとして圧力を加えたとたん，パイプがつまって しまうような例も希る。デイラタンシーは堅い無機物の 球状でない結晶粒子が含まれているときと抏こりやす い。粒子同志のすべりが悪く，かくはんによって粗雑な 構造になりやすいからである。

いま一つの異常な流動の例で有名なのはチキソトロピ - (thixotropy) である。初めに例にあげたトマトケチ ヤップや，化粧用乳液などで静置して抢くと固化してゲ ル状となり，振ると液状のゾルとなって流出するような 現象でめる。

塗料工業でもチキソトロピーを利用している。ペンキ には適度のチキソトロピーがほしい。ブラシで塗るとき は軟化して液状になっているのが塗りやすい。塗り終っ た後はすぐ固化してもらわないと壁面から流れて落ちて しまう。といって余り早く固化するとハケ目が残って見 苦しい。適当なチキソトロピーを持ったものが望ましい といらことになる。

\section{5 粘 弾 性}

さきに述べたようにある物質が完全弾性体であれば， 一定の外力 $S$ に対して一定の変形 $ミ か ゙$ 瞬間的に発生し, それ以上変形は増えも減りもしない。また外力を取去る と変形は瞬間的に消失する。このような場合はさきに述 べた式 (1)の関係が成立する。

$$
S=E \varepsilon
$$

またニュートンの完全粘性流体であれば一定の外力 $S$ に対して一定の流動が起こって止まることがない。その ときの式はさきの $(3)$ である。

$$
S=\eta\left(\frac{d \varepsilon}{d t}\right)=\eta \cdot D
$$

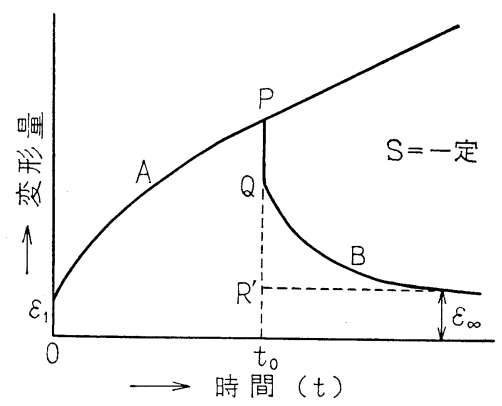

図-6 クリープ曲線 $\mathrm{A}$ と回復曲線 $\mathrm{B}$ 


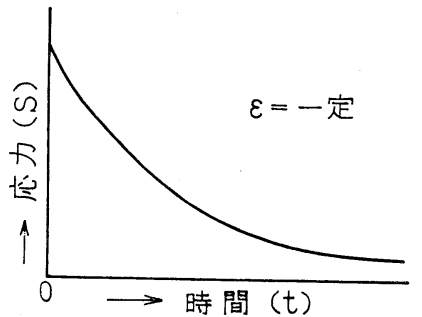

図-7 応力緩和曲線

高分子物質，たとえばポリエチレンのひもに一定の荷 重をぶらさげておくと，図-6のような变形 $と$ と時間と の関係が得られる。

まず一定の荷重 $S$ を加えたとたんに，変形 $\varepsilon_{1}$ を生じ る。この変形 $\varepsilon_{1}$ は式 $(1)$ の関係を満足している。一定 の荷重 $S$ を加えたままにしておくと次第にひもはたれ下

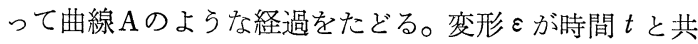
に増加することは，あたかも流動しているようである。 弾性変形と粘性流動が重なっている。このよに一定荷重 に対して变形が時間と共に次第に増加していく現象をク リープ (creep) という。長く坐ったあとに衣服にしわが よるのは繊維のクリープである。

曲線 $\mathrm{A}$ の途中 $\mathrm{P}$ 点で外力 $S$ を取去る（ $S$ は時間 $t$ によ がって変化しない)。変形には瞬間的になくなる部分 $\mathrm{PQ}$ と時間の経過と共になくなっていく曲線 B の部分とから で減少していくが，一般には变形がにになで下がらな い。ある值 $\varepsilon_{\infty}$ に近づく。この曲線Bの過程をクリープ の回復 (creep recovery) といい, $\varepsilon_{\infty}$ を永久变形という。 クリープの起こる系では式 (1)のEはもはや定数でな く，外力を加えてから变形を測定しょうとする時までに 経過した時間 $t$ の関係になる。クリープの起こる試料で は外力 $S$ に対して, 同じ大きさの内部応力 $S$ が生じて釣 合っているがこの応力が時間と共に減少していくことに なる。一定の変形を保つために外力 $S$ をだいに減らし てやることが必要で，そのときそれに釣合う内部応力も 減少している。一定の变形に対応した応力が減少するこ とを応力緩和 (stress relaxation) といい，その模様は 図-7 のようである。応力 $S$ は時間と共に 0 にならない で $S_{\infty}$ といら一定の值になることが多い。

応力緩和は弾性変形に内部の粘性流動が重なって出て きたものであるから，このような性質を粘弾性（viscoelastic properties) といい，弾性と粘性の中間の性質で あり，図-1 の YA 間あたりの物性である。高分子物質 はこの粘弾性的な物性をもった代表的な物質であろう。 金属などに比べて分子構造中に内部で滑りやすい（流動 しやすい）部分をもっているからである。

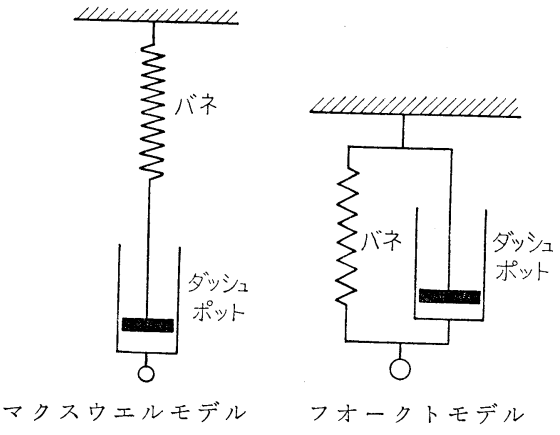

図-8 粘弾性の二要素モデル

プラスチックの板を折り曲げる場合, 加える外力は同 じであってもゆっくりやればたくさん曲がり, 速くやる とあまり曲がらないことがある。同じ力であっても繰り 返す速さによって曲がる度合が異なる。加える力が充分 に大きいときは，ゅくりのときはあめのように曲がり， 速いときは，ガラスのように割机てしまう。この違いは プラスチックなどはゆっくりした外力に対しては粘性体 のように流動し, 速い外力に対しては弾性体として変形 する。中間の速さでは粘弾性の性質を示す。このように 繰り返しで行なわれる力学的な刺激に対し, 粘性とも弾 性ともつかぬ性質を動的粘弾性 (dynamic visco-elasticity）といら。これに対しさきのクリープや応力緩和は 静的粘弾性 (static viscoelasticity) と呼んでいる。

粘弾性を解釈していくにはさきの式 (1)と (3)が基礎 となるが，話しを簡単にするために模型を考えておこ ら。弾性はバネで, 粘性流動はダッシュポット (dush pot）で表わすと，その力学的組合せは直列と並列があり, それぞれをマクスウェルモデル (Maxwell model) とフ オークトモデル(Voigt model) と呼んでいる。（図-8）

まづマスクスウェル模型の孝古る。下のにぎりを 急に引張ると弾性を表わすバネが伸びる。ゆっくり引っ 張るとバネは伸びずにダッシュポットのピストンだけが 伸びる。中間の速度で引張れば両方がある割合で伸びて きて粘弾性が現われてくる。特に引張っておいてそのま まの長さに保持していると（変形を一定にしておく）, バネは自然に縮んでピストンを引張り上げていくから (流体の性質が表らわれてくる)，応力はだんだん減少 していく。これは応力緩和を表現している。

数式的な取扱いはつぎのようになるバネの变形を $\varepsilon_{1}$, ダッシュポットの变形を $\varepsilon_{2}$ とすれば式 $(1)$ と式 $(2)$ と より,

$$
\begin{aligned}
& S=E \varepsilon_{1} \\
& S=\eta\left(\frac{d \varepsilon_{2}}{d t}\right)
\end{aligned}
$$


式(1)を時間 $t$ で微分すると

$$
\frac{d S}{d t}=E\left(\frac{d \varepsilon_{1}}{d t}\right)
$$

マクスウェル模型では，バネとダッシュポットのそれ ぞれの变形の和が全体の变形であるから

$$
\frac{d \varepsilon}{d t}=\frac{d \varepsilon_{1}}{d t}+\frac{d \varepsilon_{2}}{d t}=\frac{1}{E}\left(\frac{d S}{d t}\right)+\frac{S}{\eta}
$$

$E$ とクは時間に関係のない常数である。 いま，変形をを一定に保つと，

$$
\varepsilon=\text { 定数 } \quad \frac{d \varepsilon}{d t}=0
$$

となり，その条件で式(10)を積分すると，

$$
S=S_{0} \exp (-t / \tau) \text {, ただし } \tau=\eta / E
$$

となる。ての単位は時間であり，これを緩和時間（relaxation time) と呼び，Lが大きいと応力緩和がしにく く，小さ汿ればしやすい物質である。

マクスウェル模型で外力 $S$ を一定にすると, $d S / d t=0$ となり式(10)は

$$
\frac{d \varepsilon}{d t}=\frac{S}{\eta}
$$

となる。これはニュートンの粘性流動そのものの式にな って粘弾性を表現しない。この場合は粘弾性の表示にこ の式はなじまない。

マクスウェルモデルは有名な Maxwell が 1868 年に 示した概念であり，やわらかい餅や，溶融しかかったプ ラスチック類はこのマクスウェル粘弾性に近い。

フォークト模型では，バネとダッシュポットが並列に 結ばれた場合で，外力Sによってバネが伸びようとして も並列に付着したダッシュポットの抵抗のために変形が 減速されて徐々にしか進行しない。バネがSに対する一 定の変形にに達したところで停止してしまう。その点が マクスェル粘弾性の場合と異なる。あたある時刻で $S$ を 取去っても瞬間的には回復しない。弾性と粘性のかね合 いでじわじわと縮んでいく。力 $S$ が一定であるからさき のクリープに相当する現象を表わしている。

式で表わすと，バネとダッシュポットが並列に結ばれ ているから，つねに両者の変形は等しい。

$$
\begin{aligned}
& S_{1}=E \varepsilon \\
& S_{2}=\eta\left(\frac{d \varepsilon}{d t}\right)
\end{aligned}
$$

全体の力 $S$ は $S=S_{1}+S_{2}$ であるから

$$
S=S_{1}+S_{2}=E \varepsilon+\eta\left(\frac{d \varepsilon}{d t}\right)
$$

$S$ を一定に保っているから，式(15)を積分すると

$$
\varepsilon=\frac{S_{0}}{E}\left[1-\exp \left(-\frac{t}{\lambda}\right)\right] \text { ただし } \lambda=\eta / E
$$

となる。 $S_{0} / E$ はダッシュポットがないと考えたときの
瞬間弾性変形で図-6 の $\varepsilon_{1}$ に相当する。 $\lambda$ は変形の出現 の遅れ方を時間によって示したもので，遅延時間（retardation time) と呼んでいる。

フォークトモデルでは変形を一定にすると, 式(15)で $S=E \cdot \varepsilon$ となり，弾性变形だけの式になり粘弾性を示さ ない。フォークトモデルはV Voigt (1890) の考へたもの で, 非常に粘度の高い液体を吸い込んだスポンジ，包装 に使われる軟質ポリエチレンや可塑剤の入ったポリ塩化 ビニルのフィルムがこの粘弾性を示す。これらは引張る とゆっくりと伸び，力を取り去るとゆっくりと元に㞔 る。

粘弾性は粘性と弾性の重なり合ったものであり,これ を二つの力学的モデル（マクスウェルとフォークトモデ ル）をとり入れて重なり方の様子を少しばかり具体化さ せた。しかし力学的モデルはまくまで物質よりつくられ た物体の力学的性質の外見だけを表現するものであって その物質の内部構造とは直接には関係してこない。また 物質の複雑なレオロジ一的な性質を簡単な前述の二要素 モデルで説明できない。三要素モデルとか四要素モデル などが考光られる。

たとえば図-9 は四要素モデルの一例であるが，これ はさきの図-6 ものクリープ曲線 $\mathrm{A}$ と回復曲線 B とをう まく説明できる。図-9 の $\varepsilon_{1}$ は瞬間弾性变形で， $E_{1}$ の ヒズミである。曲線 $\mathrm{A} の \mathrm{P}$ 点までは， $E_{2}$ と $\eta_{2}$ のフォー クトモデルと $\eta_{3}$ のダッシュポットのヒズミであり, $\mathrm{P}$ 点で充分クリープした状態になっている。ここで力 $S$

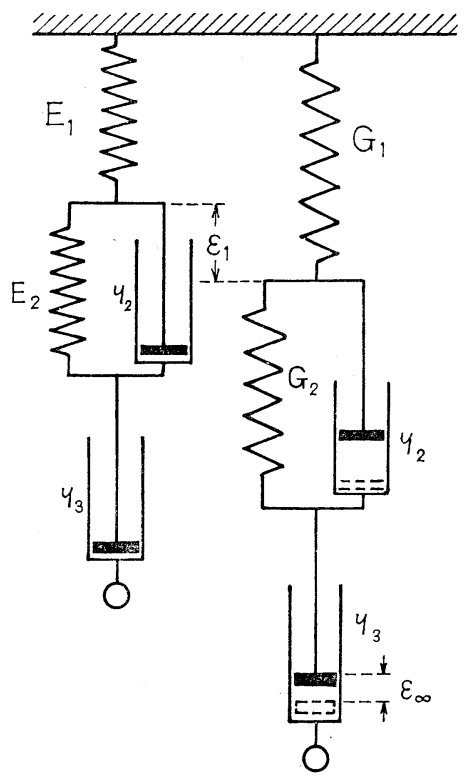

図-9 粘弾性の四要素モデルの一例による変形 
を取去るとたちまち $\mathrm{PQ}$ だけの瞬間弾性変形が回復す る。これは $E_{1}$ のバネに対応した $\varepsilon_{1}$ に相当する。それ からあとの回復曲線 $\mathrm{B}$ は $E_{2}, \eta_{2}$ のフォークトモデルに よる回復であり, これを遅延弾性回復と呼び, 残った永 久変形 $\varepsilon_{\infty}$ はダッシュポット $\eta_{3}$ が受けもっている。 式で示すと

$$
\begin{aligned}
{[\text { 全変形 }]=} & {[\text { 瞬間弾性変形 }]+[\text { ク } 1-フ ゚ \text { 変形 }] } \\
= & {[\text { 瞬間弾性変形 }]+[\text { 遅延弾性回復 }] } \\
& +[\text { 永久変形 }]
\end{aligned}
$$

のなる。

実際の高分子物質のレオロジー的性質を忠実に表現し
ようとすれば，高分子物質は結晶部と非晶部とが共存し ている二相系であり，また多分子性で分子の寸法がいろ いろと異なっているものの統計的な混合物であり,さら に橋カケしているものもあるし，水素結合などで比較的 かたく結合していたり，単なるからみ合いをしているる のもあるのでもっと複雑な多要素モデルが必要となる。 しかし実用上はそんな複雑な多要素モデルを考えても， それらはその物質の外観上の力学的性質を再現するだけ であって本質的な意味をもってこない。物質の構造に直 接関係させた粘弾性理論がまだ完成していないからであ る。労多くして功少なしといえよう。 